\title{
UPGRADING THE TECHNOLOGICAL CAPABILITIES OF FOREIGN TRANSNATIONAL SUBSIDIARIES IN DEVELOPING COUNTRIES: THE CASE OF ELECTRONICS IN THAILAND
}

\author{
Paper submitted to \\ Research Policy
}

Michael Hobday* and Howard Rush**

January 2006

This paper is based on work supported by the World Bank entitled: 'Technological Capability Building in Thailand'. The views expressed here are those of the authors and not necessarily those of the World Bank. The normal disclaimers apply.

*SPRU: Science and Technology Policy Research University of Sussex

e-mail m.g.hobday@susx.ac.uk
**Centre for Research in Innovation Management (CENTRIM)

University of Brighton, e-mail:H.J.Rush@bton.ac.uk 


\begin{abstract}
Although substantial research shows the importance of transnational corporations (TNCs) to export led growth in some developing countries, it cannot be assumed that TNC subsidiaries will automatically upgrade their capabilities through time or in a uniform fashion. This paper explores the pattern and pace of a sample of exporting TNC subsidiaries operating in the electronics industry in Thailand. The analysis reveals a wide variety in capability building approaches through time, with some subsidiaries failing to develop capabilities and remaining as 'assembly only' plants. Other more dynamic plants developed process engineering and product design skills, investing heavily in capability building. One common determinant in capability building appears to be the overall technology strategy of the parent plant. In those subsidiaries which did not upgrade beyond assembly, technology decisions and processes were tightly controlled within the parent headquarter (HQ) locations. By contrast, the more dynamic plants exercised more discretion over local capability building. The latter were relatively decentralised and more open to policies to encourage upgrading. The study suggests that governments should tailor upgrading policies not only according to the approximate level of capabilities attained by local subsidiaries, but also according to how receptive firms are to upgrading, arguing that capability building and policy receptiveness go hand-in-hand. Other countries hoping to upgrade the quality of foreign direct investment might also wish to focus policies on the more technologically capable, ambitious and receptive categories of foreign subsidiary.
\end{abstract}




\section{Introduction}

Research indicates the importance of foreign direct investment (FDI) to the export led growth and technological catching up in several of Asia's newly industrialising economies (NIEs). Some transnational corporation (TNC) subsidiaries in countries such as Singapore and Malaysia have made considerable progress in upgrading their technological activities over time. This progress is sometimes presented in 'stages' models which try to capture the overall historical progress of TNCs in regions such as South East Asia. However, innovation studies in both developed and developing countries consistently show that 'all firms are not the same' in their strategies and practices towards technology. Therefore, there is no reason to assume that all firms will upgrade technologically through stages. Nor is there any reason to assume that upgrading will occur automatically or in a uniform fashion across firms. As yet, research has not yet examined in any depth the differences in rates and patterns of technological upgrading of TNC subsidiaries or the policy implication of any variety in upgrading patterns.

The purpose of this paper is, therefore, to explore the pace and pattern of TNC technological upgrading in one major export sector, electronics, in Thailand. As in the case of other South East Asian economies, such as Singapore, Malaysia, Indonesia and Vietnam, Thailand's export sector has been dominated by foreign TNC subsidiaries producing electronics hardware including consumer goods, computing and telecommunications equipment, hard disc drives and semiconductor components. It is interesting from a developmental perspective to see whether and to what extent technological capability building has occurred across different types of TNCs. It may also be useful from a policy perspective to more deeply understand the trends, motivations and limitations of capability building in TNC subsidiaries, so that governments are better placed to encourage the upgrading of the quality of capabilities in both new and existing FDI.

Because of the lack of previous research on the comparative upgrading paths of TNC subsidiaries, an exploratory case study approach was adopted, based on in-depth interviews with structured sample of 15 electronics exporting subsidiaries of various kinds within Thailand. ${ }^{1}$ Case material was gathered to explore and compare the strategies and practices of different types of TNC towards upgrading. We were especially interested in the motivations, barriers and encouragements to technological upgrading and to understand the decision making process regarding capabilities from the point of view of the subsidiaries themselves. Using a simple 'benchmarking' technique, the research broadly categorised the subsidiaries according to levels of technological capability achieved. Interviews with directors, managers and engineers were used to explain the factors which underpinned upgrading paths and decisions. The cross-firm comparisons resulted in interesting differences between subsidiaries. To complement the cross-case analysis and provide more detailed insights into how extensive upgrading can occur, we also present one particular 'exemplar' case of successful capability building illustrating the stages, processes and strategies involved and the motivations underpinned capability building.

\footnotetext{
${ }^{1}$ Thailand is an interesting case as the TNC subsidiaries are often viewed as lacking in technological capability and 'behind' the levels of more advanced economies such as Singapore and Malaysia (see Part 1).
} 
The paper proceeds as follows. Part 1 presents recent research on the technological development of TNC subsidiaries in Thailand and other South East Asian economies, pointing to the limitations of capability building stages models. Part 2 presents the sample design, method and field evidence examining (a) variety in level of capability building and possible explanations for this (e.g. size of firm, product grouping, age of firm and corporate strategy) (b) explanations for observed differences, according to different categories of TNCs. Part 3 presents the in-depth case example of an American firm (Seagate Technology) which upgraded significantly in Thailand over the past two decades, creating a burgeoning of local technological capability within the disc drive industry. ${ }^{2}$ Part 4 assesses implications for industrial and innovation policies for governments which are attempting to promote more rapid upgrading among TNCs.

Although the focus of the paper is on a single country and one cannot generalise from one country to the next, we hope that the findings will have relevance both to other South East Asian economies which rely heavily on electronics producing TNCs for export growth, and for other developing countries hoping to encourage local TNC subsidiaries to increase their rates of technological upgrading.

\section{Part 1: TNCs and Technology Upgrading}

Table 1: Technological Upgrading of TNC Subsidiaries in South East Asia

\begin{tabular}{|l|l|l|l|l|l|}
\hline & Singapore & Malaysia & Thailand & Indonesia & Vietnam \\
\hline $1960 \mathrm{~s}$ & Assembly & & & & \\
\hline $1970 \mathrm{~s}$ & $\begin{array}{l}\text { Process } \\
\text { Engineering }\end{array}$ & Assembly & Assembly & & \\
\hline $1980 \mathrm{~s}$ & $\begin{array}{l}\text { Product } \\
\text { Development }\end{array}$ & $\begin{array}{l}\text { Process } \\
\text { Engineering }\end{array}$ & Assembly & Assembly & Assembly \\
\hline $1990 \mathrm{~s}$ & R\&D & $\begin{array}{l}\text { Product } \\
\text { Development. }\end{array}$ & $\begin{array}{l}\text { Process } \\
\text { Engineering }\end{array}$ & $\begin{array}{l}\text { Process } \\
\text { Engineering }\end{array}$ & Assembly \\
\hline
\end{tabular}

Source: based on empirical research (see text for references)

Compared with countries such as South Korea and Taiwan, the major South East Asian economies have depended to a large extent on TNC subsidiaries for export growth. Table 1 presents a simple 'stages model' to summarise research into technological upgrading in the electronics sector. TNC subsidiaries began exporting in Singapore, starting with simple assembly operations in the 1960s and progressing to more advance process engineering in the 1970s and then to minor product improvements in the 1980s (Hobday, 1995). Research shows an increase in research

\footnotetext{
${ }^{2}$ Although Seagate is not necessarily typical, it represents a useful historical case of successful developmental.
} 
and development (R\&D) during the 1990s as wages rose and skills improved (Wong, 1992; 1998).

The TNC subsidiaries in Malaysia began their activities in the 1970s, again with assembly. Technology transfer from parents enabled the expansion of export factory production and a progressive upgrading of both production processes and the type of products being exported. While there was nothing especially new in TNC technology transfer to Malaysia (or indeed Singapore), prior to this TNC investments had occurred mainly to serve domestic markets or to engage in tariff hopping, rather than export production.

Despite observed technological learning at the plant level and the use of successively higher levels of technology, Malaysia and the other South East Asian economies remained somewhat behind Singapore through the 1980s and 1990s, lacking in R\&D and new product development capabilities (Ariffin and Bell, 1998; Bell et al, 1996; Rasiah, 1994). However, the TNC subsidiaries in Malaysia and Thailand acquired useful manufacturing process skills and some limited product design capabilities and in some cases, limited R\&D activities. ${ }^{3}$ A similar pattern began to appear in Indonesia and Vietnam but in these cases the TNCs had yet to achieve the levels of capability development of earlier entrants. ${ }^{4}$

Case study research indicates that, typically, the main focus of the TNC subsidiaries has been acquiring and upgrading technical and engineering skills aimed at assimilating and improving existing technology, rather than $R \& D$ activities for new product or process innovation. Some studies (e.g. in Malaysia) show that the subsidiaries struggled for many years to overcome obstacles and invested heavily in human resources to acquire technology from their parents. ${ }^{5}$ Firm-level research in Singapore, Malaysia and Thailand shows that some subsidiaries have learned to innovate over time and now play significant roles within the overall TNC production (e.g. in semiconductors in Malaysia and hard disc drives in Thailand).

Researchers in the field point out that there is nothing 'automatic' in these stages of development and that they are, at best, merely rough historical representations of general progress (Ernst et al. 1998; Hobday, 2003). These types of models should not be used to imply that all firms follow the general path or that, in the future, lagging firms will necessarily follow the path of leading firms. Instead, the proper use of such interpretations is in the spirit of Gershenkron who used simple stages models to identify deviations, diversity and differences in patterns of development and was hostile to using stages models deterministically or in a prescriptive manner (Gershenkron, 1962). However, despite these caveats, as yet there has been very little

\footnotetext{
${ }^{3}$ For stages in general in Thai industry, see Intarakumnerd and Virasa (2002); for firm-level development stages see Chairatana (1997); for electronics in Thailand see Poapongsakorn and Tonguthai (1998).

${ }^{4}$ See Ca and Anh (1998) for Vietnam and Thee and Pangestu (1998) for Indonesia.

${ }^{5}$ See Ngoh (1994) for the case of Motorola and Lim (1991) for the case of Intel.
} 
research on whether or not there are different propensities of TNC subsidiaries to upgrade technologically. ${ }^{6}$

From an historical perspective these findings on technological upgrading should not be particularly surprising. They are consistent with early research on international product life cycles (Vernon, 1966; 1975) and theories regarding the location of production (Dunning, 1975). Vernon (1966) for example, argued that TNC subsidiaries would initially locate production of mature, standardised products in low cost locations. The findings are also consistent with advanced country research on how TNCs distribute and integrate their global subsidiary activities (e.g. Bartlett and Ghoshal, 1989; Ghoshal and Nohria, 1989). These studies show that TNCs rely on their networks of subsidiaries to manufacture and, in some cases, to innovate. Over time, it is natural for some subsidiaries to mature and become world product design centres and/or centres of excellence for particular technological activities (Kogut, 2002; Fratocchi and Holm, 1998) indicating that significant innovative activities have transferred to the subsidiary. Technological improvements by subsidiaries can be an effective way to promote the overall growth and competitiveness of the TNC network (Egelhoff et al 1998). ${ }^{7}$

Some research on subsidiary initiatives (Birkinshaw, 1997) criticises earlier studies which focused on the contrast between local and global markets in understanding subsidiary upgrading (e.g. Bartlett and Ghoshal, 1989). Birkinshaw (1997) argues that subsidiary initiatives are, in fact, the manifestation of dispersed corporate innovation and entrepreneurship. The initiative process typically involves the identification of an opportunity at the subsidiary level, subsequent negotiations with the headquarters and, finally, the commitment of resources to a new initiative by the HQ.

However, it is clear that in some countries TNC technological upgrading does not necessarily occur despite high profile and costly policies of encouragement, as in the case of the Brazilian telecommunications sector. In the developing world, Brazil is second only to China with respect to the volume of FDI attracted during the 1990s to DCs. Quantitatively the policy of attracting FDI can be considered successful (Lacerda, 2003). However, from an upgrading perspective there are major concerns. For example, to attract and upgrade FDI, tax incentives granted since 1993 to manufacturers of telecommunications equipment exceeded US\$3 billion over the period 1993 to 2003) ${ }^{8}$. Case study research suggests that three of eight observed subsidiaries (Siemens, Motorola and Ericsson) upgraded their role in the TNC network allowing them to participate more strongly in global product development (Galina and Plonski, 2002; Galina, 2003; Perini, 2004a,b). Nevertheless, despite the

\footnotetext{
${ }^{6}$ For a rare exception see Guyton (1994) who argued that Japanese consumer electronics firms were reluctant to transfer technology to Malaysia. This particular study did not examine other TNC nationalities, or the impact of 'age' of investment in technology transfer performance.

${ }^{7}$ These findings were developed mainly within Canada (Birkinshaw, 1997) and then expanded to other developed countries where subsidiaries have proved effective in promoting growth (Holm and Pederson, 2000; Delany, 1998; Egelhoff et al., 1998).

${ }^{8}$ The Information and Communications Technology Law (for details see Brasil 2004, Tax Law. Embassy of Brazil in London).
} 
large investments output indicators such as patent and publications suggest that Brazilian subsidiaries remain fairly insignificant within the overall innovation activities of the respective TNCs and R\&D remained very limited. The sustainability of these policies is surrounded by great controversy within Brazil.

Within this context, research on electronics within Thailand shows the importance of innovation for upgrading at the sectoral level (Brimble 2001) and the varied progress of locally-owned firms as they acquire technology (Intarakumnerd and Virasa 2002; Chairatana, 1997). Poapongsakorn and Tonguthai (1998) point to the need for technological capability building to sustainability the export success of Thailand in both electronics and textiles. Arnold et al (2000) provide general guidance on how to assess and enhancing policy support for industrial technology development within Thailand. Unfortunately, there is little published firm or sectoral level data on electronics within Thailand, especially with respect to the exporting TNC subsidiaries. Therefore, we adopted an multi firm exploratory study to enable in-depth case research and cross-firm comparisons to begin to build a picture of technological progress in this sector.

\section{Part 2: Analysing the TNC Subsidiaries in Thailand}

\subsection{Method and approach}

Electronics exports from Thailand, as in other fast growing countries of South East Asia, are mostly based on two types of TNC subsidiary, called here 'primary' and 'first-tier'. Primary TNCs are those which first came to Thailand, usually to produce finished goods or components. As the initial plant investments they tend to start with simple assembly operations and then incrementally learn production technology according to decisions taken by the foreign corporate HQ. First-tier TNCs are suppliers of components and semi-finished products, which came later to Thailand, usually to supply the primary TNCs with necessary inputs as production expands. Sometimes first-tier firms then diversify to produce not only for their primary TNC customers but also for the wider international market.

To analyse subsidiary upgrading, a combination of methods was required, including documentation analysis, questionnaires for gathering data on capability development, and a method for comparing upgrading across firms. Following standard methods for multiple case study research, we built up a sample of firms sufficient in number to examine the paths and patterns of technological progress at the individual firm level, and to compare and contrast results across firms (Pauwells and Matthyssens, 2004; Straus and Corbin, 2004; Yin, 1994; Miles and Huberman, 1994; and Eisenhardt, 1991). As with all exploratory research, the intention was not to generalise our findings to the entire population but to establish robust findings and arguments for further study. By choosing a diverse range of cases, we were able to explore variety in patterns of change and to interrogate findings by comparing results across firm size, product range, ownership, corporate strategy and duration of operation.

In order to assess the level and path of upgrading, a questionnaire was designed based on the previous studies which examine the movement of firms through levels of capabilities (e.g. Bessant et al, 2001; Arnold et al 2000). We used a simple 'staircase 
model' of capabilities running from weak (Level A), moderate (Level B), strong (Level C) to very strong (Level D). We then adapted the staircase model to correspond to main technological stages described in Table 1 above, where Level A corresponds to assembly activities, Level B to process engineering, Level C to product development, and Level D to R\&D capabilities.

Within the framework, firms which focus on assembly (Level A) have little need for technological effort or investment beyond maintaining production process quality. They will tend to have a small number of technicians and engineers focused on production quality. Process engineering oriented firms (Level B) will generally employ substantial numbers of technicians and engineers, and will be capable of setting up, modifying and perhaps making minor improvements to production process technology. Firms which concentrate on product development (Level C) will have mastered process engineering and have the capabilities to design new products and organise production processes for these new products. Level $\mathrm{C}$ is a wide band that incorporates firms with the ability to make incremental improvement to existing products and those with the capabilities for designing new products. These firms will employ a significant number of design engineers and may well have a formal product engineering department. Firms with R\&D capabilities (Level D) will have a full complement of process and product engineering, and substantial R\&D capabilities and will typically have an R\&D department. While other firms may carry out some limited R\&D, to be included in this category a firm would have to be able to contribute to the world technology frontier through $R \& D$ via the generation of new products or processes. As noted, firms may pass through the various stages as they develop, but there is nothing automatic about progress.

The purpose of the framework and questionnaire was not to achieve a precise measure of capability but to gain a rough benchmark to assess each TNC plant and compare them against each other. For each firm, case material was gathered on numbers of R\&D, engineering and technician staff, types of equipment used, the main focus of production activities, relationships with $\mathrm{HQ}$, tools and frameworks for analysing technology, links with local institutions and suppliers, the decision making process with respect to technology, future strategies and areas of technical strength and weakness. Historical information was also gathered on technological progress, milestones and difficulties in order to roughly gauge the progress of each firm since start up. External sources of information on the company's history, number of employees, turnover and products manufactured were also gathered (e.g. from the Internet), checked and updated during the interviews.

\subsection{Sample design}

As noted earlier, the electronics sector was chosen because it is the largest industrial export sector in Thailand and has led the country's export growth over the past two decades or so. It is also likely to continue to be important to Thailand's future international trade. Table 2 presents details of the firms audited. To protect confidentiality, code numbers were allocated instead of company names, according to size, product type, age of firm and so on (see Table for an explanation of the coding system). Fifteen firms were selected according to the two types of TNC (primary and first-tier) identified above. The choice of 15 firms was largely determined by convention regarding multiple case study research, and determined by the need (a) to gather sufficient data for understanding each case in depth and (b) to make cross firm 
comparisons. The choice of 15 firms enabled us to structure a sample sufficiently large to make comparisons according to: (a) ownership of the firm, comparing most of the various foreign-owned nationalities (e.g. American, Japanese, European, Korean and Taiwanese were included); (b) the various types of product manufactured (see below); (d) different categories of company size; and (e) length of operation within Thailand. The sample enabled us to explore whether any observed differences in technological capability building related to these factors in any way.

Regarding limitations, the sample does not necessarily correspond to the overall structure of the Thai electronics industry in terms of population of electronics firms or total value of production. This is partly because there is a lack of basic data on the overall industry (e.g. total employment, sales and exports by product type) and no published studies of TNCs operating within the sector. Nevertheless, both large and very large firms were included and the sample did include a significant share of the overall industry with a total employment of more than 43,000 staff. Also, the sample was sufficiently large to capture several of the key causes of variety in terms of technology capability paths.

As described in Table 2, the 15 TNC suppliers were made up of eight primary electronic product and component exporters (code T1) and seven first-tier suppliers (T2) of finished components, component parts, and sub-assemblies to primary companies). First tier supplier firms generally followed primary firms into Thailand and were generally more recent entrants. We learned that most of these firms had expanded their customer base to supply other TNCs outside of Thailand. Like primary firms, all first tier suppliers production was for export, either directly or indirectly via primary firms. 
Table 2: TNC Subsidiary Sample: Electronics in Thailand

\begin{tabular}{|c|c|c|c|c|c|c|c|c|c|}
\hline $\begin{array}{c}\text { Firm Category and } \\
\text { Code Name }\end{array}$ & Start Date & $\begin{array}{c}\text { Plant } \\
\text { Employment } \\
2002 \\
\end{array}$ & $\begin{array}{c}\text { Overall } \\
\text { Audit Level }\end{array}$ & $\begin{array}{l}\text { Export } \\
\text { market } \\
\text { Share }^{10}\end{array}$ & $\begin{array}{l}\text { Owner } \\
\text { ship }^{11}\end{array}$ & $\begin{array}{l}\text { Main Product } \\
\text { Lines }\end{array}$ & $\begin{array}{c}\text { Business/ } \\
\text { Technology } \\
\text { strategy }\end{array}$ & $\begin{array}{c}\text { Qualified } \\
\text { engineers } \\
\text { (total) }^{12}\end{array}$ & $\begin{array}{c}\% \text { of } \\
\text { engin- } \\
\text { eers }{ }^{13}\end{array}$ \\
\hline \multicolumn{10}{|l|}{$\frac{\text { Type T1: Primary }}{\text { TNCs X8 }}$} \\
\hline T1AUV & 1982 & 13000 & $\mathrm{C}$ & $100 \%$ & US & $\begin{array}{c}\text { HDD } \\
\text { manufacture } \\
\text { and test }\end{array}$ & $\begin{array}{l}\text { Upgrade to } \\
\text { higher } \\
\text { technology } \\
\text { manufacture }\end{array}$ & 500 & $3.8 \%$ \\
\hline T1BEV & 1974 & 4100 & $\mathrm{~B}-\mathrm{C}$ & $100 \%$ & $\begin{array}{l}\text { Europe } \\
\text { an }\end{array}$ & $\begin{array}{l}\text { Semiconductor } \\
\text { assembly and } \\
\text { test }\end{array}$ & $\begin{array}{l}\text { Upgrade to } \\
\text { higher } \\
\text { technology } \mathrm{mfr} \text {. }\end{array}$ & 120 & $2.9 \%$ \\
\hline T1CTL & 1990 & 2000 & B-C & $100 \%$ & $\begin{array}{c}\text { Taiwan } \\
\text {-ese }\end{array}$ & $\begin{array}{l}\text { PC display and } \\
\text { monitor } \\
\text { production } \\
\end{array}$ & $\begin{array}{c}\text { Upgrade to } \\
\text { higher } \\
\text { technology } \mathrm{mfr}\end{array}$ & 106 & $5.3 \%$ \\
\hline T1DUL & 1984 & 1500 & $\mathrm{C}$ & $100 \%$ & US & $\begin{array}{l}\text { Semiconductor } \\
\text { assembly and } \\
\text { test }\end{array}$ & $\begin{array}{l}\text { Upgrade to } \\
\text { higher } \\
\text { technology } \mathrm{mfr}\end{array}$ & 150 & $10 \%$ \\
\hline T1EJL & 1990 & 1100 & A-B & $100 \%$ & $\begin{array}{l}\text { Japane } \\
\text { se }\end{array}$ & $\begin{array}{l}\text { Semiconductor } \\
\text { assembly and } \\
\text { test }\end{array}$ & $\begin{array}{l}\text { Mature product } \\
\text { assembly }\end{array}$ & 60 & $5.5 \%$ \\
\hline T1FTL & 1989 & 1029 & A-B & $100 \%$ & $\begin{array}{l}\text { Taiwan } \\
\text {-ese }\end{array}$ & $\begin{array}{c}\text { Resistor } \\
\text { assembly and } \\
\text { test }\end{array}$ & $\begin{array}{l}\text { Mature product } \\
\text { assembly }\end{array}$ & 40 (e) & $3.9 \%$ \\
\hline T1GJL & 2000 & 1000 & A-B & $100 \%$ & $\begin{array}{c}\text { Japane } \\
\text { se }\end{array}$ & $\begin{array}{l}\text { Printer, fax, PC } \\
\text { assembly }\end{array}$ & $\begin{array}{l}\text { Mature product } \\
\text { assembly }\end{array}$ & $30(\mathrm{e})$ & $3.0 \%$ \\
\hline TIHJL & 2000 & 980 & A-B & $100 \%$ & $\begin{array}{l}\text { Japane } \\
\text { se }\end{array}$ & $\begin{array}{l}\text { Semiconductor } \\
\text { assembly and } \\
\text { test }\end{array}$ & $\begin{array}{l}\text { Mature product } \\
\text { assembly }\end{array}$ & $35(\mathrm{e})$ & $3.6 \%$ \\
\hline
\end{tabular}

\begin{tabular}{|c|c|c|c|c|c|c|c|c|c|}
\hline $\begin{array}{l}\text { Type T2 - First-tier } \\
\text { TNC suppliers X7 }\end{array}$ & & & & & & & & & \\
\hline T2IJL & 1987 & 4,500 & A-B & $100 \%$ & $\begin{array}{l}\text { Japane } \\
\text { se }\end{array}$ & $\begin{array}{c}\text { Audio } \\
\text { components } \\
\text { (wide variety) }\end{array}$ & $\begin{array}{c}\text { Mature } \\
\text { component } \\
\text { assembly for } \\
\text { TNCs }\end{array}$ & 300 & $6.7 \%$ \\
\hline T2JJL & 1985 & 3500 & A-B & $100 \%$ & $\begin{array}{c}\text { Japane } \\
\text { se }\end{array}$ & $\begin{array}{c}\text { Telecom } \\
\text { components }\end{array}$ & $\begin{array}{c}\text { Mature } \\
\text { component } \\
\text { assembly for } \\
\text { TNCs }\end{array}$ & 120 & $3.4 \%$ \\
\hline T2KKL & 1991 & 440 & A-B & $100 \%$ & Korean & $\begin{array}{l}\text { Audio/telecom } \\
\text { components }\end{array}$ & $\begin{array}{c}\text { Mature } \\
\text { component } \\
\text { assembly for } \\
\text { TNCs }\end{array}$ & 11 & $2.5 \%$ \\
\hline
\end{tabular}

\section{Notes/explanations}

9 Explanation of coding (using first example, TIAUV):

$\mathrm{T} 1=$ Type of TNC $(\mathrm{T} 1, \mathrm{~T} 2)$

$\mathrm{A}=$ Alphabetical code of company interviewed (A-O, i.e. 1-15)

$\mathrm{U}=$ Ownership: $\mathrm{U}=\mathrm{US}, \mathrm{J}=\mathrm{Japan}$, E-Europe, $\mathrm{T}=$ Taiwan, $\mathrm{K}=$ Korea, $\mathrm{M}=$ Malaysia; $\mathrm{L}=$ Local (Thai), $\mathrm{Q}=$ Japan-Taiwan joint venture

$\mathrm{V}=$ Company size by employment (refers to plant audited, not to company overall): $\mathrm{V}=$ very large (>3000); L = Large (1000-2999); M= Medium Size (300-999); S=Small (10-299);

${ }^{10}$ Includes both direct exports and indirect (i.e. components for TNCs destined for export);

${ }^{11} \mathrm{Q}=$ Japanese-Taiwanese joint venture;

12 Defined according to job task (e.g. design or production engineering); normally with batchelors or masters degree in engineering

13 Calculated as percentage of total staff (not including technicians); estimates marked 'e' 
Table 2 (cont'd): TNC Subsidiary Sample: Electronics in Thailand

\begin{tabular}{|c|c|c|c|c|c|c|c|c|c|}
\hline T2LQM & 1992 & 340 & A & $100 \%$ & $\begin{array}{c}\text { Japane } \\
\text { se- } \\
\text { Taiwan } \\
\text {-ese } \\
\text { Joint } \\
\text { Ventur } \\
\text { e }\end{array}$ & $\begin{array}{l}\mathrm{PC} \text { and TV } \\
\text { components }\end{array}$ & $\begin{array}{c}\text { Mature } \\
\text { component } \\
\text { assembly } \\
\text { for TNCs }\end{array}$ & 10 & $2.9 \%$ \\
\hline T2MJM & 1995 & 320 & A-B & $100 \%$ & $\begin{array}{l}\text { Japane } \\
\text { se }\end{array}$ & $\begin{array}{l}\text { Components } \\
\text { for audio, } \\
\text { computers }\end{array}$ & $\begin{array}{c}\text { Mature } \\
\text { component } \\
\text { assembly for } \\
\text { TNCs }\end{array}$ & 10 & $3.1 \%$ \\
\hline T2NMM & 1999 & 300 & $\mathrm{C}$ & Local & $\begin{array}{l}\text { Malay- } \\
\text { sian }\end{array}$ & $\begin{array}{l}\text { Equipment and } \\
\text { components for } \\
\text { HDD assembly }\end{array}$ & $\begin{array}{c}\text { Equipment } \\
\text { supply for } \\
\text { TNCs } \\
\end{array}$ & 20 & $6.6 \%$ \\
\hline T2OUS & 2000 & 30 & $\mathrm{C}$ & Local & US & $\begin{array}{c}\text { Equipment for } \\
\text { PCB }^{14} \\
\text { assembly }\end{array}$ & $\begin{array}{c}\text { Equipment } \\
\text { supply for } \\
\text { TNCs }\end{array}$ & $8(\mathrm{e})$ & $2.7 \%$ \\
\hline
\end{tabular}

To assess the role, if any, of ownership nationality, the sample included most nationalities including six Japanese companies, three American, one European, two Taiwanese, one Korean, one Malaysian and one Japanese-Korean joint venture. In order to see whether plant size influenced innovation progress, the sample covered a wide spectrum of sizes with four plants 'very large' (defined as having more than 3000 employees) and five large (having between 1000 and 2999 employees). A further five were medium sized (with between 301 and 1000 employees) and one was small (10-299 employees).

The electronics exporting industry in Thailand consists of several product families. In order to see whether product family related to capability building, a wide range of products and components were included in the sample, covering most of the electronics product groups made in Thailand. Some firms produced more than one product line and operated in more than one particular sub-sector. The main product lines represented in the sample were:

- Semiconductor (integrated circuit) assembly and testing: 4 cases

- Other components (e.g. resistors and transformers): 2 cases

- Hard disc drives (HDD) and HDD components: 2 cases

- Audio equipment and components: 3 cases

- Telecommunications products and components: 2 cases

- PC and TV monitors and components: 2 cases

- Complete PC and PC components: 2 cases

- Machinery for assembly: 2 cases

- General printed circuit board assembly (PCBA): 1 case

The sample included a spread of start-up dates in order to see whether the age of the plant influenced the degree of capability, the presumption being that more recent entrants may not yet have had time to establish their technological roots, whereas earlier entrants have had more time to build up capabilities. Dates of incorporation in Thailand included four cases if recent entrance (from 1999 to 2002), five cases of start

\footnotetext{
${ }^{14} \mathrm{PCB}=$ Printed circuit board.
} 
ups between 1990 and 1995, four cases of start up between 1984 and 1989, and two cases of start ups prior to 1984 .

\subsection{Capability development comparisons}

The study results revealed a wide spread of capabilities across different electronics sub-sectors, ownership nationalities and plant sizes in Thailand, although almost all had progressed beyond level A (assembly) to process (level B) and product engineering (level C).

Of the sample of 15 firms, one fitted into the assembly category, eight were spread around the upper band of assembly and the lower band of process firms (on the boundary between level A and B). Two plants were located between process and the product engineering categories ( $\mathrm{B}$ and $\mathrm{C}$ ) with most focussing on process but with some design capability. The remaining four firms were fully designated product engineering firms with one or two of these conducting some limited R\&D. Not surprisingly, none of the subsidiaries were capable of contributing to the world technology frontier through R\&D or new generation products (Level D), although several were engaged in new product development activities. The one assembly only firm was a Japanese-owned first tier supplier. Of the eight on the boundary between assembly and process, six were Japanese-owned, one was Korean and one Taiwanese (four were primary firms and four were first tier suppliers). Of the product engineering firms, our third category, three were American and one Malaysianowned.

During the interviews, various possible explanations for different rates of technological upgrading were developed and explored. For example, was this due to: (a) the nature of the product type or family? (b) the stage of development of the firm (as proxies by the date of incorporation)? (c) the size of the firm and plant in question? or (d) the corporate and technology strategy of the HQ? It is useful to review the finding against each of these possible explanations in turn.

First, regarding the nature of the product type or family, a lack of technological progress did not appear to relate to the nature of the product in question. In some areas (e.g. semiconductors) some firms had quickly moved beyond the assembly/process categories, onto product engineering developments, having invested substantially in engineering capability (e.g. T1DUL and T1BEV), whereas others in the same product family had made little progress (e.g. T1EJL). In other product areas too (e.g. audio and telecommunications) there were examples of both assembly/process and product engineering firms, indicating that product type was not a determining feature of efforts towards local capability building.

Second, as far as stage of development is concerned, some firms had started more than a decade ago (e.g. T1FTL, T1EJL and T21JL) but had remained at the first two levels. Others had entered at approximately the same time (or more recently) and had built significant technological capabilities (e.g. T2NMH, T2OUS and L1QLL), indicating that start-up date (as a proxy for phase of development) was not a major factor in capability building.

Third, turning to the size of the plant in question, again, this did not appear to be a key factor in capability development. On the contrary, two of the smaller firms were at 
the product engineering level, while some of the larger firms were categorised as falling within the assembly or process categories. Also, some small and medium sized firms were also of the assembly/process type, suggesting that firm size was not a significant factor in technology development.

Fourth, the corporate technology strategy explanation appeared to carry more weight as an explanatory factor. Analysis of the eight assembly/process boundary level TNCs (plus the one fully fledge assembly level firm) shows that six were Japaneseowned, one was Korean, one Taiwanese, and one a Thai-Japanese joint venture. By contrast, most of the higher scoring TNCs were American- and European-owned. As discussed below in more detail, the main explanation had to do with the technology strategies adopted by the Asian TNCs (Japanese, Korean and Taiwanese firms). Technology decision-making within the subsidiaries appeared to be tightly controlled by the parent HQs and only that technology strictly required for assembly was transferred or developed locally by the subsidiary. This applies both to the primary TNC producers and even more so to the first-tier suppliers. Although designated as assembly-process level firms, the interviews revealed that these firms employed highly competent and experienced managers and engineers. However, they operated within a corporate environment where technology, capital (and other) investment decisions took place mostly in the HQ location (e.g. in Japan or in Korea) and their task was to implement these decisions efficiently. Decisions not to develop technology in Thailand appeared to be part of a wider, coherent strategy towards global markets and technologies. This is not in any way a negative assessment, but simply reflects the decision to retain technological (and usually marketing and financial) control within the parent headquarters, sometimes jointly with leading (e.g. Japanese) customers and technology/equipment suppliers within the HQ country. It is also conceivable that this could be partly the result of geographical proximity to the local subsidiary. American and European subsidiaries were much further away from their respective HQs than the Asian ones perhaps encouraging more decentralisation.

For the more passive subsidiaries, decisions were taken to focus efforts on assembly and manufacture rather than process development. The data show that even this 'more limited' task requires substantial technical and engineering support to ensure efficiency and to make minor improvements to flows of production and so on. For example, the case of one Japanese firm (T21JL) although categorised as assemblyprocess (Levels A-B) employed around 300 engineers (6.7\% of total staff). Other firms in this grouping also employed significant numbers of engineers in order to ensure efficiency and flexibility in output. The main role of this (substantial) engineering effort appeared to be organisation and improvement of the shop-floor activities which underpin productivity of assembly operations.

However, within the more tightly controlled decisions and technology structures of the Asian TNCs there was little plant level demand for significant technology upgrading because of the wider corporate strategy. These strategic differences appeared to be aligned with nationality, with Japanese and other Asian firms opting for a more centralised technology strategy approach, and Western (US and European) firms tending towards a more decentralised approach. However, it is important to note that these differences were a matter of degree. The more decentralised American and European plants, for example, only went 'so far' in capability building and the local subsidiaries did not have complete autonomy, as one would expect. In the 
American owned firms, for example, final decisions on capital and technology investments were taken at the parent headquarters (or in close consultation with the HQ) based on the relative advantages of different locations in other parts of Asia and elsewhere. However, if subsidiary managers could make a case for local upgrading, and the parent HQs saw benefits in a relatively high degree of technology decentralisation and the building up of local subsidiary capabilities, then investments could take place. By contrast, in the case of Japanese owned firms, for example, there was little propensity for local technology upgrading beyond that required for current manufacturing (which in itself can be quite demanding), and therefore, as argued below, little receptiveness to government policies for upgrading.

The two American primary firms (producing semiconductors and hard disc drives) had progressed quite far in terms of capability building, and both were product engineering (Level C) subsidiaries. Generally, the first-tier TNC suppliers lagged behind the primary TNCs, being mainly assembly - process companies, again mostly Japanese owned. Of the two most dynamic process engineering companies, one was American-owned and one Malaysian-owned. Both of these produced equipment rather than components, and both had produced or were developing new equipment for the Thai electronics industry in collaboration with their parent companies, suggesting the small beginnings of a capital goods equipment industry in electronics in Thailand.

\subsection{Factors underlying capability upgrading in primary TNCs}

As Table 2 shows, of the eight primary firms, three (two American and one European) could be identified as being process - product (Levels B-C), indicating significant technological capability and strategies in place for further technological upgrading. These firms were dynamic companies operating under fairly decentralised corporate strategies. They had demonstrated their capabilities and were given encouragement by HQ to expand and move up the value chain of activities that, in turn, required them to absorb substantial engineering capabilities for operating and developing manufacturing processes. The three firms were strongly networked into other subsidiaries and the parent HQ, so that they could assimilate knowledge, solve local problems and move to new processes and products quickly. The three benefited from organisational innovations such as continuous improvement, quality circles and statistical process control methods as well as local engineering capacity. However, they had not yet moved onto significant new product development, nor R\&D. Nevertheless, they looked forward to building new capabilities in the future and were open to linkage forming within the local economy. They were receptive to policy encouragement (e.g. participating in government vendor development schemes and forming linkages with local technical colleges and universities).

By contrast, four (3 Japanese and 1 Taiwanese) of the eight primary companies were assembly - process (Level A-B). Managers in these four companies were aware of technological trends and strategies, but operated within a more controlled corporate environment that strictly limited local innovation activities. The parent strategies were centralised in the sense that that there was very little need to upgrade subsidiary capabilities beyond that required for current production needs, as decisions and developments were conducted in the HQ. In contrast to the US and European TNCs, these firms were geographically much closer to their HQs and this fact might have played a role in the 'closeness' of the parent HQ relationship. In these cases, almost 
all significant engineering decision-making (e.g. choice of capital goods, installation of machinery, new product and process development) were taken by HQ, sometimes linked into customers and suppliers in the home location. ${ }^{15}$ These firms had acquired the engineering and technician capabilities required for assembly operations, often for lower cost mature product lines which were no longer produced in the home country. The case of one assembly - process firm (TIEJL) is particularly interesting, as although it was in the same product semiconductor family as (TIBEV) and fell into the process - product category, it had developed far fewer capabilities, indicating that product type, and length of stay, were not the main determinant of technological upgrading, but rather the strategy of the company concerned. Like the more dynamic primary companies, the passive subsidiaries were actively engaged in organisational innovations including total quality management (TQM), continuous improvement and quality circles, important to production efficiency. Several firms reported that they had achieved impressive cost reductions arising from these efforts. Managers said that given their assembly task, their engineers were most appropriately focused on achieving operational efficiency in assembly, rather than acquiring additional or new technology.

In each primary firm, the main determinant in technological transfer and local capability development was overall corporate strategy and, in particular, the way the Thai subsidiaries fitted into the international division of technological and production activities. This is not entirely surprising, as it would be highly unlikely that a subsidiary would act independently of, or in conflict with, the overall strategy of the parent. In this sample of firms, strategy was closely associated with ownership and geographical proximity, and this group of factors appeared to be more closely associated with technology capability building say compared with product type or date of start up.

Needless to say, in the assembly only plants, no R\&D was undertaken or contemplated. These firms represented low cost, basic production capacity for the parents. Although in some cases senior engineers and directors of these plants were highly aware of global technological trends and strategies, having relocated from the parent plant, in areas such as capital goods modification, technology acquisition and implementation, and exploiting external linkages with universities and technical colleges, these firms were largely inactive and had very low capabilities in these areas, simply because these capabilities were not required within Thailand. There was no need for local technological effort within the business strategy and this was reflected in the lack of technological autonomy and discretion at the subsidiary level.

By comparison, the American and European TNCs boasted much stronger capabilities (e.g. in HDDs and semiconductors). The one European firm (T1BEV) had considerable technological strengths in capital goods selection and implementation, production engineering, product-process engineering, incremental product improvement, and had a range of projects for new technology developments underway at the local plant supported by locally trained engineers and managers.

\footnotetext{
${ }^{15}$ For example in cases T1EJL and T1HJL new product decisions were made at HQ in consultation with the suppliers of capital goods. These decisions were then relayed to the subsidiary.
} 


\subsection{Capability building in first-tier TNC subsidiaries}

Evidence from the sample of seven first-tier subsidiaries confirms the above view that Japanese and Korean firms tend to operate under more centralised and 'technologically closed' corporate environments than American and European TNCs. Four of these firms had reached the assembly - process level and a further one involved only in assembly. The five had entered Thailand to supply primary firms, sometimes at the direct request of the primary TNC exporters, with necessary inputs which had previously been imported. This applied to a wide range of product lines including audio, telecom, PC and TV monitors. Some firms had diversified their local client base and exported directly to customers in other external markets.

These five firms were mostly engaged in the production of simple, mature products using low cost labour. Production processes were basic and assembly-oriented. Rudimentary technician skills were evident but only those required for current assembly needs. HQ staff took engineering tasks and decision-making with respect to production and, when necessary, engineers were dispatched from HQ to resolve operational difficulties. Most production took place on fairly mature, well proven lines for standard products no longer produced in the home country of the parent. In these plants, at least up until the time of research, there was no need or demand for acquiring technological capabilities.

Within the group of seven first-tier suppliers there were, however, two examples of dynamic product engineering subsidiaries (T2OUS and T2NMM). Both were equipment suppliers to the primary TNCs. One was a medium-sized Malaysian company that had entered to supply high technology production machinery to the primary TNCs. The other was a small American subsidiary that also supplied high technology assembly equipment. In both cases, customer demand required relatively strong local technological capabilities and a conscious strategy for technology acquisition and upgrading was followed. Neither plant were yet at the stage of producing radical new products based on original research but both had significant engineering and development capabilities and both looked forward to further technology upgrading.

\section{Part 3: The Case of Seagate Technology Thailand (STT)}

Among the most successfully upgrading TNCs in Thailand was the American firm Seagate Technology Thailand (STT). As a case study, STT shows in more detail the stages a successfully upgrading TNC, running through levels A (assembly), to B (process engineering) to $\mathrm{C}$ (product development). It also presents the typical motivations, on the part of both the subsidiary and the parent, which underlie extensive technological capability building. Furthermore, it indicates the length of time it takes to upgrade, taking several decades to achieve its relatively advanced stage.

Within Thailand, the subsidiary grew from around 50 employees in 1982 to more than 35,000 in 1999. In order to expand assembly and engineering and to achieve higher quality, STT invested considerably in training and process engineering in the area of hard disc drive (HDD) production. The local subsidiary earned itself a corporate wide 
reputation for innovative process design, high quality output and low defect production. As a result of plant expansion, second-tier TNCs entered Thailand to support STTs operations. Substantial technology transfer was made possible through local technological efforts, with foreign engineers and managers being replaced by Thai staff, up to and including chief executive officer level.

\section{Level A: start up and assembly production}

STT began as a very small HDD assembly operation with around 50 employees in 1982. The company was the first foreign HDD producer to set up in Thailand. By the late 1990s, STT employed the largest concentration of Seagate employees world-wide and almost half of the company's total employees. All of STTs production was for the export market, mostly for other Seagate plants.

Table $3 \underline{\text { STTs five production plants }}$

Location Establishment Total

Date Employment

$\begin{array}{lll}\text { Plant 1 - Chockchai - } & 1987 & 3,329 \\ \text { Plant 2 - Teparuk plant - } & 1988 & 13,267 \\ \text { Plant 3 - Rangsit - } & 1994 & 1,959 \\ \text { Plant 4 - Wellgrow- } & 1994 & 7,695 \\ \text { Plant 5 - Korat } & 1996 & 8,442 \\ & & \\ \text { Total } & & 34,692\end{array}$

Source: Interviews, Company Reports

In the late 1990s, the three main production process steps carried out in Thailand were (a) head assembly (b) stack assembly and (c) drive assembly. Seagate in Singapore carried out the next stage in the process which is the final assembly of the HDD. (Malaysia and China also carried out drive assembly). The main Chokchai plant focused on two HDD product lines, low cost desk top PC HDDs, and high cost, high performance workstation PCs. The various components for the HDDs were imported or purchased locally, but not produced in the Chokchai plant which concentrated on assembly which is a highly complex, multi-stage process.

Level B: early technology transfer 1982-1988

When STT began in 1982, the main motivation for locating in Thailand was low labour costs. Although production scale was very small (i.e. assembly shop), high profit margins soon induced Seagate to begin production in many different locations around the Bangkok area. This expansion proceeded rapidly in various buildings on an ad hoc basis, driven by the need for capacity expansion. Although small scale, even at this early stage (1982-1988) the quality required and the nature of the assembly process itself demanded fairly intensive technical support. Around 15-20\% of employees were engineers and technicians, including a high proportion of foreign engineers during this period. Technology was initially transferred informally by the more experienced foreign engineers to local engineers and technicians. As local 
technical staff became more experienced and more senior, they in turn recruited and trained new Thai staff.

Substantial technical support was required not only for plant start up, but also to monitor and control HDD yields, ensure consistency of materials and the high quality and reliability expected by the HDD buyers (mostly large PC makers, such as IBM, Dell and Texas Instruments). During this period, STT learned the 'art of HDD assembly' in Thailand, gaining experience in assembly, capital equipment, testing and quality technology.

\section{Advanced Level B: take off and major plant expansion: 1989 onwards} In 1989, the first major plant, Teparuk, was established, bringing together the small units, and marking a new phase of technological capability building. With increasing levels of HDD integration and ever higher quality demands, production became more automated and technology-intensive. Engineering was initially centralised to promote support for the various stages of production. By 1999 STT's Chokchai plant employed around 1,500 technically qualified staff (10\% of the total staff employed), of whom around 500 were engineers and 1,000 or so technicians of various kinds. Engineers cover all the basic tasks of HDD assembly including, plant start up, capital goods installation and modification, tooling, maintenance, process engineering (including statistic process control), quality engineering, software development and failure analysis. Within engineering, there were 15-20 PhDs, and large numbers of masters degree holders. The minimum qualification for engineer in STT was a bachelors degree. Technicians normally held a qualification of some kind (e.g. a diploma). All staff received substantial in-house organised training and on-the-job training. As a relatively high paying employee within Thailand, STT confronted no major shortages of technically qualified staff from local universities and colleges.

In 1999 the central engineering department was re-organised in favour of a distributed 'product life concept' in which all staff, including engineers, were allocated to specific product groups. This strategy, aimed to raise productivity through teamworking and to increase the subsidiary's speed and flexibility in response to customer needs.

Level B involved intensive, if incremental 'behind the technology frontier', innovation. Competition, both among the corporate subsidiaries and with other HDD assemblers located in Thailand, forced the pace of innovation, both within STT and the company's major competitors. As is normally the case with catch up innovation, this process did not require much $R \& D$ but instead called for incremental improvements to manufacturing processes, machinery and equipment, and changes to the way production was organised.

To remain competitive in terms of quality and cost, one of the tasks of engineering at STT was to remove non-value adding elements from the production process and to organise production in the most efficient and flexible way possible. Routine engineering tasks included the improvement and re-configuration of testing equipment, tooling, fixtures, quality assurance methods and materials. Raising productivity also depended on more creative, non-routine engineering task and problem-solving projects. One such project began in 1996, which involved the creation of a new cell (i.e. team)-based approach to production (of around 55-60 
operators to each cell). In order to improve production yields, each production line was converted into a semi-permanent team or cell, with the aim of instilling greater ownership among staff of processes and problems. At the start, defect parts per million (DPPM) was around $2 \%$, (i.e. $98 \%$ yield) considered to be too high, leading to substantial rework and waste material. With the new cell system each time there was a problem (e.g. with yield levels or tooling) the production line was shut down and the team had a meeting to identify causes and solutions. Initially, under the new system yields fell to $93 \%$ (7\% DPPM), as groups spent time identifying and resolving process problems. After two weeks or so, overall yield was back up to $95 \%$ and by the fourth week yields has reached 99.5 to $99.6 \%$.

This organisational innovation brought about significant benefits, for example, in the reduction of scrap material, the lowering of inventory and improved quality. Productivity continued to rise as a result of the system, leading to current DPPM levels of $0.05 \%$ (virtually defect free). American management, surprised by the high yields at STT, visited to verify the results and learn about the techniques used. As a result, the cell system spread to the rest of Seagate plants, providing an example of 'reverse technology transfer' from subsidiary to parent.

As with many innovations, the cell system was not without its disadvantages. Teams sometimes got 'set in their ways' and it became more difficult for management to allocate resources, given the need to maintain cells as units. The system also called for a great deal of training in the initial stages (around 15,000 employees required some training). Re-training was also required to increase cell flexibility (e.g. with new product generations) to allow for better overall resource allocation. A second innovation was led by a $\mathrm{PhD}$ engineer who devised new analytical technique for gathering data for configuring HDD test procedures. This method was accepted internally and then presented to final customers, including IBM, for approval. Again, the system was widely adopted by Seagate, producing significant process improvements in testing. Incremental innovation also applied to some of the capital goods used, most of which were imported from the US (e.g. most testing equipment was imported). In the case of tooling, prototypes were purchased from the US, then STT engineers tested, maintained and re-programmed the software controls according to local needs.

While there was no R\&D department in 1999, there was a need for local engineering capability to feed back to a new product design centre in Colorado. US design engineers visited the plant regularly, providing a technology channel to the subsidiary and vice versa. In addition, the two operations had a direct data link and, equally importantly, kept in touch over the phone to relay back important data to help configure new products and processes developed in the US.

\section{The process and nature of capability building}

One interesting dimension of the STT case is the shift from informal to formal capability building. In the early days training was informal, with engineers going back and forth to the US for training on particular aspects of HDD production. By the late 1990s, training and retraining was highly organised. Each employee received roughly four weeks training per year. The training department, which employed between 100 and 300 people at the Chokchai plant, depending on training needs, was responsible for delivering training to the 15,000 employees. During times of change 
(e.g. the introduction of new product lines) new trainers were recruited in from the operating lines, expanding the training department up to the 300 level. All operators received initial, formal training in the 'classroom' and then on-the-job, and all received a training certificate once they have passed a test. All technicians and engineers also received regular training. Training, as with most activities, was carried out in the Thai language, with the addition of a few technical English terms.

A second dimension of capability building was the need to begin to develop a supply chain within Thailand. Most of the key components (e.g. read/write heads, wafers and sliders) were imported from the US and Singapore. Only relatively simple products were purchased locally (e.g. wire). However, several major foreign suppliers followed Seagate into Thailand, forming a first tier of TNC suppliers to the local plant (e.g. Minibea and TPW) to supply components such as springs and stacks. TPW, for example, entered from Singapore to supply stacks for the STT plant. Overall, according to managers, there were too few local suppliers to support the needs of STT and imports continued at a high level.

A third facet of capability building in this case was the eventual forming of linkages with external public sector organisations. Up until 1996, STT was too focused on its own growth to develop linkages with university groups and government organisations. However, in 1999 the firm began discussing issues with Asian Institute of Technology and several of the major universities. STT had begun to donate equipment to support university R\&D and offered a class on HDD technology. STT saw the benefits flowing in both directions, with the universities better able to support STT with inputs of personnel as a result of closer collaboration.

A fourth dimension of capability building was the devolution of some decision making to the local plant. Given the very short product life cycles for HDDs (as low as 6 to 9 months in some cases), local speed and flexibility of STT were key factors driving capability development. STT needed to be able to take independent decisions in the manufacturing. However, as a subsidiary the plant had no say in overall corporate strategy, including new product development, future sales or marketing. Nevertheless during the latter stages, it had become closely involved in the corporation's manufacturing strategy. By the late 1990s, the local Chief Executive Officer, an engineer by training, a Thai, had become a Senior Vice President of the company. One of his tasks was to feed back new manufacturing developments to the board. Regarding new plant expansions, changes to process, volume targets and so on, these were proposed by STT, discussed and agreed with HQ. Implementation was then a matter for STT. By 1999 there were very few foreign ex-patriots involved and most of the senior management and technical staff were Thai nationals.

In summary, the case of STT provides an interesting example of how extensive technological capability building can occur through the various stages outlined in Part 1 , within an economy not widely known for its technological achievements.

However, there were no rigid stages and the case of STT followed its own particular path which, as discussed earlier, differed from that of other TNC subsidiaries. Interestingly, the technological capability upgrading which went on within STT also occurred in STT's main HDD competitors, most of whom operated in Thailand. STT routinely benchmarked its own performance against its rivals, usually when hiring-in 
engineers from these companies, and found similar technical performance and productivity levels.

\section{Part 4: Policy implications}

While one cannot draw direct lessons for policy from firm level information alone, the evidence provides some interesting policy insights both for Thailand for other countries wishing to encourage TNC subsidiaries to 'climb the technology ladder'. It is highly likely that in most DCs with substantial FDI a wide variety of capabilities exist, as in the case of Thailand. Therefore, it is probably wise to tailor government policies and programmes to the different categories of subsidiary. It is also highly unlikely that any single policy towards upgrading could address the range of different capabilities and approaches taken by TNCs.

The evidence suggests that policy should take into account at least two dimensions of capability building (a) level of capability achieved and (b) the desire and need of firms to upgrade local subsidiaries, which is closely linked to 'policy receptiveness'. Policy receptiveness refers to the extent to which individual TNC are decentralised in terms of technology operations and willing and able at the local subsidiary level to engage with policies and institutions which support upgrading.

Take for example, assembly firms (level A) which are policy receptive and willing and capable of upgrading. Here government policies might focus on supporting the supply of basic technician and engineering skills. Government may consider supporting collaborative projects involving colleges, universities and local technology institutes, which look forwards to future technological needs, perhaps centred on process engineering, product-process interfacing and product improvement, or vendor upgrading programmes to increase the local supply of inputs. If subsidiaries are able to engage productively in such collaborative activities, then they may be able to bargain more effectively with their parent HQ for further investments in upgrading, say compared with subsidiaries in competing countries which do not have such programmes. Such collaborations may also build up understanding and trust between the TNCs and other local actors.

Similarly, policy receptive process engineering-oriented Level B firms might already be in a position to work with government agencies, universities and local institutes on advanced automation technologies, product design projects and perhaps R\&D projects in support of process and product design. This could assist in the supply of human resources and encourage a more rapid upgrading than would otherwise be the case. Involvement in university MBA programmes might also be useful to support the development of the next level of managers required, and professors and students might be encouraged to engage in projects involving the development of new strategic frameworks for technological acquisition and developments so that priorities can be established and addressed. Progress in upgrading might require a systematic searching for local technology solutions to particular business and technology problems and local institutes might be able to assist here. Firms, such as Seagate, could be further encouraged explore experimental new approaches to new product design and process quality with staff and $\mathrm{PhD}$ students at universities. In the longerterm, this might assist the receptive subsidiaries to develop an internal capability for 
R\&D and lead on to new public sector support initiatives of the kind common in Singapore for example (Wong, 1998; Hobday, 1995).

Firms capable of product improvement and new product development (Level C) might benefit from projects involving advanced technical research and business strategy development (e.g. focused on technology roadmaps for particular lines of product) and the challenging of firms to 'think outside of the box' as occurs in some MBA projects. Government may try and encourage consultants or specialist research organisations to work with subsidiaries at Level $\mathrm{C}$ on advanced projects to develop the next generation of capital goods or new products.

Regardless of how capable a firm is, the Thai study suggests that policies to encourage upgrading are best not directed at all firms in general, but towards specific firms or groups of firms which are receptive to upgrading policies. There is little to be achieved by encouraging subsidiaries to build capabilities if this runs counter to the strategy of the parent corporation. By contrast, policies which focus on receptive firms could potentially speed up the rate of upgrading. It is highly likely that both variety in capability and policy receptiveness exists in other countries, which implies that that government agencies should focus on firms which are amenable to policies for capability building. It is equally unlikely that TNCs which are highly centralised in terms of technology strategy and investment decisions will respond to domestic policies for upgrading as there is little need for local capability building. By contrast, where TNCs follow decentralised strategies and where subsidiaries have a degree of discretion in technological upgrading, then policy makers have a fertile ground for supporting and encouraging capability building.

In Thailand the TNC subsidiaries which were not receptive to upgrading, not only tended to be centralised in terms of strategy but also operated within a relatively 'closed' technological environment within Thailand. In these cases, technology decisions were defined by the parent company and subsidiaries were far less open to policy encouragement. Technology requirements for local subsidiaries were decided up by the parent according to company's overall strategy. In effect, this meant that there was little desire to move towards subsidiary level engineering, new product development or R\&D. By contrast, TNC subsidiaries (e.g. the more advanced American firms such as Seagate Technology Thailand) operated within a more open corporate technological system which was amenable to local incentives and opportunities for upgrading. These types of firm could benefit from policies which support local engineering developments within the domestic economy.

This does not mean that government agencies need to evaluate firms or to 'pick winners'. Indeed, they may not have the skills or resources to do this. In practise, receptive firms are fairly easy to identify as they tend to respond to policy initiatives and requests for information as they are motivated to exploit external linkages in order to make the case for upgrading within the TNC. In effect, they are 'selfselecting' in terms of policy. Some of these firms have championed technological upgrading in Thailand (e.g. in HDDs and semiconductors) and these same firms might be encouraged to further accelerate their pace of capability building. Their incentive is strengthen their corporate case for further upgrading in the light of competition both (a) from other subsidiaries of the same firm in other countries and (b) subsidiaries from other TNCs in the same country. Focusing on these firms might enable 
government to exploit 'stage accelerating' opportunities. Put simply, receptive firms should be the focus of policy rather than those which are not receptive to upgrading local plants.

If sufficient numbers of subsidiaries in the same sector are policy receptive, policies may wish to go beyond encouraging individual firms to upgrade to consider how to upgrade networks of receptive firms engaged in similar activities. For example, the Thai Government is keen to encourage 'clusters' to develop to promote innovation and competitiveness. Although the electronics sector is not normally targeted as a potential cluster, perhaps because of the dominance of foreign-owned TNCs, in some product areas (e.g. HDDs) there may well be the potential to encourage the formulation of a high technology cluster. In HDDs, most of the major global suppliers had located in Thailand, having followed Seagate into the country. In addition, several first-tier TNC suppliers had entered to supply the primary TNCs, forming the early stages of a local supply chain infrastructure for primary TNC manufacturers.

In other countries where there is a potential for multiples cases of upgrading, governments may wish to encourage network upgrading through co-ordinating bodies such as industry associations or universities with relevant technical departments. This kind of approach appears to have worked well in Singapore and Malaysia, helping to develop horizontal synergies between firms. For example, in Malaysia the Penang Skill Development Centre was initially an industry supported training and human resource institute. Today it plans for, promotes and supports the training and technical support needs of a large semiconductor exporting cluster in Penang. The Centre is now supported by government in recognition of its important role. In both Singapore and Malaysia, TNCs are encouraged to work together on common technical problems and to support human resource developments for future needs. In addition, forward looking firm-university programmes of technology development, including research into new products and investments in public sector technical training, are deployed to encourage upgrading across groups of firms.

Government agencies and industry associations may also wish to address barriers to upgrading in specific technical fields. For example, if there are gaps in the supply of basic components, machinery, services, materials and human resources which could and 'should' be available locally, but are not available, subsidiaries are forced to import these inputs. However, if there is sufficient local demand from a group of TNC subsidiaries it may be possible to encourage local investments to fill such gaps. For example, in Thailand's electronics sector there were shortages in the area of tool making services, castings development, nickel plating services, surface mounting support and cables. Each of these areas could be a focus for government-sponsored training and human resource development perhaps based in technical colleges and universities. Also, if there are difficulties in the basic infrastructure needed for high technology manufacturing, such as in electricity and water supply, it is wise for policy makers locally and nationally to address these as they might be preventing receptive firms to upgrade or imposing additional costs on upgrading.

In the case of electronics, firms of all capability levels in Thailand found it necessary to train their own engineers, as universities and technical colleges did not fully prepare graduates for the kinds of tasks they had to undertake within the subsidiaries. 
However, some of the leading universities (e.g. King Mongut) had a strong track record in setting up engineering and information technology courses relevant to Thailand's future needs. Professors from King Mongut University had assessed the needs of the TNCs and agreed, with the TNCs, changes to their engineering courses in order to make their activities more relevant to students' future employers.

Furthermore, publicly-funded training institutes might be a route to supporting TNC upgrading. In the case of Thailand, the Thai-German Institute, a collaborate project with the German Government, operates in a zone, north of Bangkok and was developing its curricula with the participation of TNC subsidiaries. This Institute, recently established, focused on providing engineering training where shortages existed (e.g. tool and die technology). It incorporated modern facilities and hired local Thai professors to run engineering and management courses relevant to the electronics producers in Thailand. It was supported by the Thai Ministry of Industry which subsidised courses up to $70 \%$ of its cost. Another, the Japan-Thai Institute, also provided useful training to complement firm level training schemes. Such initiatives may prove useful and relevant to other nations seeking to upgrade from assembly level to technology-intensive production.

In the case of Thailand, one reason why Government is seeking to become more intensively involved in TNC upgrading is the growing competition from firms in other countries (e.g. China) which not only benefit from lower labour costs but also from an abundance of technically skilled labour. To meet low cost competition, more advanced countries such as Thailand need to constantly improve their overall infrastructure for FDI, or they may see a falling off in TNC investments in favour of China and other lower cost countries. In the case of HDDs in Thailand, the major TNCs had begun setting up plants in China. In order to sustain their presence in Thailand, the local subsidiaries had to consistently upgrade. However, this upgrading process lacked an infrastructure of support which, for example, included public sector programmes of skills and technology development and collaborative technology projects. In the case of Thailand, Government could therefore support the HDD industry to maintain its competitive advantage over China by encouraging capabilities which underpin not only operating efficiency but also new product development and research. Such opportunities may also be relevant to other countries with a substantial TNC subsidiary base which is under threat of competition from China and other low cost locations.

Policies for capability upgrading not only need to differentiate between different categories of firms and their level of receptiveness, they also need to adapt and respond to constantly changing conditions in order to lead firms forward in capability building to support competitiveness. All this indicates that policy making in this area is a complex and dynamic process and that relevant, up-to-date information is needed by policy agencies on a continuous, and low cost, basis. One very useful source of information and advice is the policy receptive firm itself. Receptive firms could potentially be used provide information and advice on: (a) appropriate government strategies for accelerating firm level technological upgrading; (b) how to expand foreign direct investment in new areas; (c) how to overcome supply chain problems; (d) develop cluster potentials; and (d) how to improve the supply of human resources from within public sector organisations such as universities and technical colleges. Feedback from the firms interviewed, showed that managers often have a good 
understanding of the problems and opportunities their plants face in the competitive environment in Thailand. This may well apply to other countries.

\section{Conclusion}

Although electronics is the leading export sector in Thailand and other South East Asian economies, its future progress cannot be taken for granted, especially with the entry of China into this sector (Lall and Albaladejo, 2003). It is important that the TNC subsidiaries which dominate this industry continually upgrade their capabilities and move towards more technologically advanced production, or they may well lose their competitive edge. Our study of 15 TNC subsidiaries in Thailand, however, shows that a wide distribution of capabilities exist among firms with some companies progressing much further than other in building technological capabilities. Some remained at assembly only (Level A), others had moved from assembly to develop process-engineering capabilities (Level B) while others such as STT had moved forward to incorporate product innovation skills (Level C).

Analysis of the nine TNCs with relatively weak capabilities suggests that technology decision-making was tightly controlled by parent HQ and only that technology strictly required for assembly was transferred by the parent or developed locally by the subsidiary. This applied not only to the primary TNC producers but also, and even more so, to their first-tier suppliers. In the case of these less dynamic TNCs, nonroutine engineering decision-making (e.g. the choice of capital goods, installation of machinery, new product development and process innovation) were undertaken by the parent in the HQ location. Decisions not to develop technology within Thailand were not negative or obstructive, but were part of a coherent corporate strategy towards global markets and technologies. Indeed, the evidence shows that substantial technical and engineering capability is required even in these, more 'passive' plants.

By contrast, the six more advanced TNCs had developed significant engineering capabilities and had strategies in place for further technological upgrading. These firms operated under relatively decentralised regimes, where offshore subsidiaries were encouraged to move up the value chain of production activities. Although these firms had not yet moved onto significant new product development or R\&D, they had strong engineering and process innovation skills and looked forward to building more advanced capabilities in the future. They were also open to linkage forming within the local economy and receptive to policy encouragement, unlike the less advanced subsidiaries which operated in more 'closed' corporate technological structures. For all firms, a major factor in local capability development was the TNC's overall corporate strategy and in particular the way in which Thai subsidiaries fitted into the international division of corporate technological and production activities.

The research suggested various policy mechanisms to encourage upgrading according to the approximate capabilities of TNC subsidiaries. These ranged from a greater supply of basic technician and process engineering skills, through to projects to encourage new product development and R\&D. Specific human resource and infrastructural barriers were identified (e.g. in areas such as tool and die making, castings, plating services and surface mounting technology) where shared facilities, supported by government have proved useful in other countries (e.g. Singapore and Hong Kong). Collaborative research projects for new generations of technology 
might also encourage TNC to look forward to future upgrading challenges and assist them in their upgrading negotiations with their parent HQ.

However, an important argument of the study, is that regardless of how capable a subsidiary is technologically, government policies are best directed towards those companies which are most receptive to upgrading. There is little to be gained by encouraging firms to build capabilities if this runs counter to the existing strategy of the parent corporation. Capability building and policy receptiveness seem to go hand in hand. Fortunately, policy receptive firms are likely to make their position well known to colleges, universities, training institutes and government agencies as it is in their best interest to support the building of a local 'upgrading infrastructure'.

Other countries may also confront variety in the capability levels of foreign subsidiaries, propensities of firms to upgrade, and policy receptiveness of TNC subsidiaries towards upgrading. If this is the case, then policy makers in other countries may also wish to consider differentiating policies according to levels of capability and receptiveness in order to focus their efforts to maximum effect. The evidence from Thailand suggests that it is wise to target policies towards groups of TNCs which are policy receptive and willing and capable of upgrading, rather than 'all firms' regardless of their technology strategies and ambitions. 


\section{References}

Ariffin, N. and Bell, M. (1998). 'Firms, politics and political economy: patterns of subsidiary-parent linkages and technological capability-building in electronics TNC subsidiaries in Malaysia', in K.S. Jomo, G. Felker, and R. Rasiah, (eds), Industrial Technology Development in Malaysia, Routledge, London.

Arnold, E., Bell, M., Bessant, J. and Brimble, P. (2000). Enhancing Policy and Institutional Support for Industrial Technology Development in Thailand. Vol 1: The Overall Policy Framework and the Development of the Industrial Innovation System, World Bank/National Science and Technology Development Agency (NSTDA) of Thailand, Washington DC.

Bessant, J., Rush, H. and Hobday, M. (2001). Assessing Technological Capabilities: An Audit Tool, Report to World Bank; Project on Korea and the Knowledge-Based Economy; World Bank, Washington.

Bartlett, C.A. and Ghoshal, S. (1989). Managing Across Borders: the Transnational Solution, Boston, Mass: Harvard Business School Press.

Bell, M.; Hobday, M.; Abdullah, S.; Ariffin, N. and Malik, J. (1996). Aiming for 2020: a Demand-driven Perspective on Industrial Technology Policy in Malaysia, Final Report to Ministry of Science, Technology and Environment (Malaysia), World Bank/UNDP.

Birkinshaw, J. (1997). 'Entrepreneurship in Multinational Corporations: The Characteristics of Subsidiary Initiatives', Strategic Management Journal, 18, 207229.

Brazil (2004). Tax Law, Embassy of Brazil in London.

Brimble, P. (2001): Technological Innovation of Industrial Enterprises in Thailand, in Regional Workshop on Innovation in the Manufacturing Sector, National Science and Technology Development Agency (NSTDA), Bangkok, Thailand, July 18.

Ca, T. N. and Anh, L. D. (1998). 'Technological dynamism and R\&D in the export of manufactures from Vietnam', in D. Ernst; T. Ganiatsos, and L. Mytelka, (ed.) Technological Capabilities and Export Success in Asia, Routledge, London.

Chairatana, P. (1997). Latecomer Catch-up Strategies in the Semiconductor Business: the Case of Alphatec Group of Thailand and Anam Group of Korea, MSc Thesis, SPRU, University of Sussex, England.

Delany, E. (1998). 'Strategic development of multinational subsidiaries in Ireland' in Multinational Corporate Evolution and Subsidiary Development, Birkinshaw, J.M. and Hood, N. (eds.), New York: St Martin's Press. 
Dunning, J.H. (1975), 'Explaining Changing Patterns of International Production: In Defence of the Eclectic Theory', Oxford Bulletin of Economics and Statistics, Vol. 41, pp.269-295.

Egelhoff, W.G., Gorman, L. and McCormick, S. (1988). 'Using technology as a Path to Subsidiary Development' in Multinational Corporate Evolution and Subsidiary Development, Birkinshaw, J.M. and Hood, N. (eds.), New York: St Martin's Press.

Eisenhardt, K. M. (1991): 'Better Stories and Better Constructs: the Case for Rigor and Comparative Logic', Academy of Management Review, Vol. 14, pp532-50.

Ernst, D.; Ganiatsos, T. and Mytelka, L. (ed.) (1998). Technological Capabilities and Export Success in Asia, Routledge, London.

Fratocchi, L. and Holm, U. (1998). 'Centres of excellence in the international firm' in Multinational Corporate Evolution and Subsidiary Development, Birkinshaw, J. and Hood, N. (eds.), London: MacMillan.

Galina, S.V.R. (2003). Desenvolvimento Global de Produtos: o papel das subsidiárias brasileiras de fornecedores de equipamentos do setor de telecomunicações. Escola Politécnica. São Paulo, USP.

Galina, S.V.R. and Plonski, G.A. (2002). 'Global product development in the telecommunication industry: an analysis of the Brazilian subsidiaries involvement' in 9th International Product Development Management Conference, Antipolis, S. (ed.), France.

Gerschenkron, A. (1962). Economic Backwardness in Historical Perspective: a Book of Essays, Cambridge, MA: The Beknap Press of Harvard University Press.

Ghoshal, S. and Nohria, N. (1989). 'Internal differentiation within Multinational Corporations', Strategic Management Journal, 10, 323-337.

Guyton, L. E. (1994). Japanese FDI and the Transfer of Japanese Consumer Electronics Production to Malaysia, Report Prepared for UNDP, K.L., Malaysia.

Hobday, M. (2003), 'Innovation in Asian Industrialisation: a Gerschenkronian Perspective', Oxford Development Studies, Vol. 31, No. 3, September 2003, pp293314.

Hobday, M. (1995). Innovation in East Asia: the Challenge to Japan, Edward Elgar, London.

Holm, U. and Pedersen, T. (2000). The Emergence and Impact of MNC Centres of Excellence: a Subsidiary Perspective, New York: St Martin's Press.

Intarakumnerd, $\mathrm{P}^{1}$ and Virasa, T. ${ }^{2}$ (2002). Taxonomy of Government Policies and Measures in Supporting Technological Capability Development of Latecomer Firms, ${ }^{1}$ Science, Technology and Innovation Policy Research Department, National Science 
and Technology Development Agency (NSTDA), Thailand and ${ }^{2}$ College of Management, Mahidol University, Thailand, NSTDA Working Paper.

Kogut, B. (2002). 'International management and strategy' in Handbook of Strategy and Management, Pettigrew, A., Thomas, H. and Whittington, R. (eds.)., London: Thousand Oaks, New Delhi: Sage Publications.

Lall, S. and Albaladejo, M. (2003). China's Manufactured Export Surge: the Competitive Implications for East Asia, Report prepared for the East Asia Department of the World Bank, Washington DC.

Lim, P. (1991). Steel: From Ashes Rebuilt to Manufacturing Excellence, Pelanduk Publications, Pataling Jaya, Malaysia.

Miles, M.B. and Huberman, A.M. (1994): Qualitative Data Analysis, $2^{\text {nd }}$ Ed. ; Thousand Oaks, Sage, CA.

Ngoh, C. L. (1994). Motorola Globalisation: The Penang Journey, Lee and Sons, K.L. Malaysia.

Poapongsakorn, N. and Tonguthai, P. (1998). 'Technological Capability Building and the Sustainability of Export Success in Thailand's Textile and Electronics Industries, in D. Ernst; T. Ganiatsos, and L. Mytelka, (eds.) Technological Capabilities and Export Success in Asia, Routledge, London.

Perini, F.A.D.B. (2004a). 'Managing innovation between global and local innovation system: coordination mechanisms in Brazilian ICT private research institutes', DRUID Summer Conference 2004: Industrial Dynamics, Innovation and Development, Maastricht, Netherlands.

Perini, F.A.D.B. (2004b). 'Micro-dynamics of subsidiary development; subsidiary initiatives, coordination mechanisms and technological capability accumulation in the Brazilian ICT sector', PRIME Doctoral Conference, SPRU, University of Sussex, Brighton, UK.

Pauwells, P. and Matthyssens, P. ( 2004): 'The Architecture of Multiple case Study Research in International Business', in R. Marschan-Piekkari and C. Welch, Handbook of Qualitative Research Methods for International Business, Edward Elgar, Cheltenham, UK.

Rasiah, R. (1994). 'Flexible Production Systems and Local Machine Tool Subcontracting: Electronics Components Transnationals in Malaysia', Cambridge Journal of Economics, Vol. 18, No.3, pp 279-298.

Straus, A. and Corbin, J (2004): Basics of Qualitative Research, Sage Publications, London.; 
Thee, K. W. and Pangestu, M. (1998). 'Technological Capabilities and Indonesia's Manufactured Exports, in D. Ernst; T. Ganiatsos, and L. Mytelka, (eds.)

Technological Capabilities and Export Success in Asia, Routledge, London.

Vernon, R. (1966), 'International Investment and International Trade in the Product Life Cycle', Quarterly Journal of Economics, Vol. 80, No. 2, pp.190-207.

Vernon, R. (1975), 'The Product Life Cycle Hypothesis in a New International Environment', Oxford Bulletin of Economics and Statistics, Vol. 41, pp.255-267.

Wong, P. K. (1992): 'Technological Development Through Sub-contracting Linkages: Evidence from Singapore', Scandinavian International Business Review, Vol. 1, No. 3. pp 28-40.

Wong, P. K. (1998): 'Patterns of Technology Acquisition by Manufacturing Firms in Singapore, Singapore Management Review, Vol. 20, No. 1, pp 43-64.

Yin, R. K. (1994): Case Study Research Design and Methods, $2^{\text {nd }}$ Edition, Thousand Oaks, Sage, CA 